\title{
Sequence and structural organization of a nif $A$-like gene and part of a nifB-like gene of Herbaspirillum seropedicae strain Z78
}

\author{
E. M. Souza, ${ }^{1}$ S. Funayama, ${ }^{1}$ L. U. Rigo, ${ }^{1}$ M. G. Yates $^{2}$ and F. O. Pedrosa ${ }^{1 *}$ \\ ${ }^{1}$ Universidade Federal do Paraná, Department of Biochemistry, PO Box 19046, 81531 Curitiba, PR, Brazil \\ ${ }^{2}$ AFRC Institute of Plant Science Research, Nitrogen Fixation Laboratory, University of Sussex, Brighton, UK
}

(Received 12 December 1990; revised 13 February 1991; accepted 18 March 1991)

\begin{abstract}
The deduced amino acid sequence derived from the sequence of a fragment of DNA from the free-living diazotroph Herbaspirillum seropedicae was aligned to the homologous protein sequences encoded by the nif $A$ genes from Azorhizobium caulinodans, Rhizobium leguminosarum, Rhizobium meliloti and Klebsiella pneumoniae. High similarity was found in the central domain and in the $C$-terminal region. The $H$. seropedicae putative NifA sequence was also found to contain an interdomain linker similar to that conserved among rhizobial NifA proteins, but not $K$. pneumoniae or Azotobacter vinelandii. Analysis of the regulatory sequences found $5^{\prime}$ from nif $A$ indicated that the expression of this gene in $H$. seropedicae is likely to be controlled by NifA, NtrC and RpoN, as judged by the presence of specific NifA- and NtrC-binding sites and characteristic $-24 /-12$ promoters. Possible additional regulatory features included an 'anaerobox' and a site for integration host factor. The $\mathbf{N}$-terminus of another open reading frame was found $3^{\prime}$ from nif $A$ and tentatively identified as nif $B$ by amino acid sequence comparison. The putative nifB promoter sequence suggests that expression of $H$. seropedicae nifB may be activated by NifA and dependent on RpoN.
\end{abstract}

\section{Introduction}

Herbaspirillum seropedicae is a free-living diazotroph found in soils and in the rhizosphere of several grasses, and has been classified as a member of the Spirillaceae (Baldani et al., 1986). It shows a broader $\mathrm{pH}$ range for $\mathrm{N}_{2}$-dependent growth and higher nitrogenase tolerance to oxygen than Azospirillum spp. It also shows low $(<20 \%)$ rRNA homology to Azospirillum spp. (Falk $e t$ al., 1986).

In Azospirillum brasilense, regulation of nif expression may be analogous to that of Klebsiella pneumoniae (Pedrosa \& Yates, 1984). Potential nif $A$ and $n t r C$ mutants of Azospirillum brasilense were complemented for nitrogen fixation by homologous genes from $K$. pneumoniae. However, the organization of these genes and the control of nitrogen assimilation in Azospirillum brasilense may be different from that in $K$. pneumoniae (Bozouklian \& Elmerich, 1986; Bozouklian et al., 1986).

\footnotetext{
Abbreviations: IHF, integration host factor; ORF, open reading frame.
}

The nucleotide sequence data reported in this paper have been submitted to GenBank and have been assigned the accession number M60319.
The dependence of nif genes on RpoN and NifA for expression has also been demonstrated in Rhizobium meliloti (Ronson et al., 1987) and Azotobacter vinelandii (Toukdarian \& Kennedy, 1986; Santero et al., 1988). Activation by NifA also occurs in Rhizobium and Bradyrhizobium spp. (Gussin et al., 1986) and in Azorhizobium caulinodans (de Bruijn et al., 1988), and the presence of a $-24 /-12$ promoter sequence suggests a dependence on $\mathrm{RpoN}$ in the majority of nif promoters sequenced to date.

The nif $A$ genes from several organisms have been cloned and sequenced. The Nif A amino acid sequences inferred from the determined nucleic acid sequences share a high degree of homology in domains $\mathrm{D}$ and $\mathrm{E}$, as defined by Drummond et al. (1986). Domain D, the central domain, appears to contain sequences homologous to ATP-binding proteins (Walker et al., 1982). Domain $\mathrm{E}$, located in the $\mathrm{C}$-terminal region, contains a helix-turn-helix motif characteristic of DNA-binding proteins; NifA also shares high homology with $\mathrm{NtrC}$ in domains D and E (Drummond et al., 1986).

A recombinant plasmid capable of complementing a nif $A$ mutant of $A$. brasilense was identified from a gene library of $H$. seropedicae strain Z78 (Souza et al., 1991). In this paper we present the nucleotide sequence of a nif $A$ - 


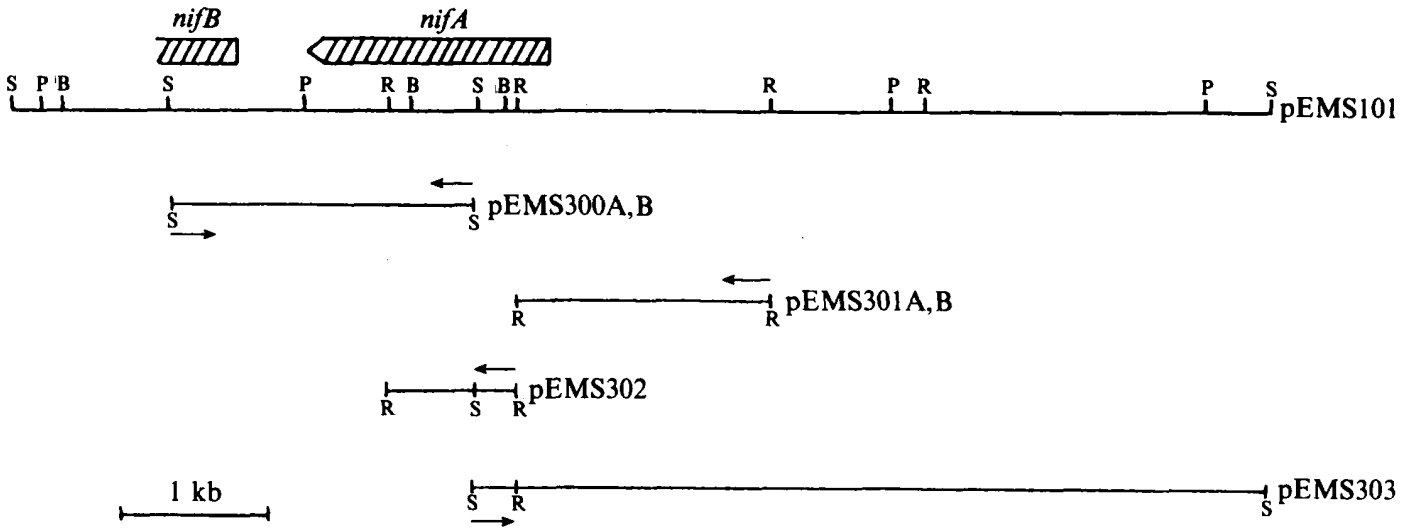

Fig. 1. Physical map and plasmids derived from pEMS101. pVK102 was the vector plasmid of pEMS101; pTZ18R was the vector plasmid of pEMS300A, pEMS300B and pEMS303; pTZ19R was the vector plasmid of pEMS301A, pEMS301B and pEMS302. The arrows indicate the direction of sequencing. Restriction sites are: B, BglII; R, EcoRI; P, PstI; S, SalI. Not all EcoRI sites are shown.

like gene from $H$. seropedicae. This sequence shows a high level of homology to nif $A$ genes from other organisms, especially to that of $A$. caulinodans. The presence of $-24 /-12$ promoter sequences and bindingsites for $\mathrm{NtrC}$ and NifA in the promoter of $H$. seropedicae nif $A$ suggests a requirement for these proteins and $\mathrm{RpoN}$ for the expression of this gene. Additional regulatory factors may include an 'anaerobox' sequence and a site for integration host factor proteins.

\section{Methods}

Bacterial strains and plasmids. Escherichia coli strains were usually grown in LB (Maniatis et al., 1982) or $2 \times$ YT broth (Bankier et al., 1987) supplemented with antibiotics as required. $E$. coli $71-18$ was kept in minimal medium supplemented with thiamin $\left(5 \mathrm{mg} \mathrm{l}^{-1}\right)$ (Maniatis $e t$ al., 1982). The phagemids $\mathrm{pTZ18R}$ and $\mathrm{pTZ19R}$ were used as sequencing vectors and the helper phage M13KO7 was grown in liquid culture and titrated on a lawn of E. coli 71-18 (Mead et al., 1986).

DNA labelling and hybridization. DNA probes were labelled with $[\alpha-$ ${ }^{32} \mathrm{PJdCTP}$ by the hexadeoxynucleotide-primed method (Feinberg \& Vogelstein, 1984). Restriction fragments from pEMS101 were separated by electrophoresis and transferred to a nylon membrane as described by Maniatis et al. (1982). Hybridizations were done under low stringency conditions $\left(35 \%, \mathrm{v} / \mathrm{v}\right.$, formamide, $\left.42^{\circ} \mathrm{C}\right)$ and were washed twice with $2 \times \operatorname{SSC}(1 \times \operatorname{SSC}$ is $0.15 \mathrm{M}-\mathrm{NaCl}, 0.015$ M-trisodium citrate, $\mathrm{pH}$ 7.0) at room temperature and twice with $2 \times \mathrm{SSC}$ at $65^{\circ} \mathrm{C}$ (Maniatis et al., 1982).

Subcloning and sequencing. Two proximal, non-overlapping DNA fragments from pEMS101 (Fig. 1), namely the $2.0 \mathrm{~kb}$ Sall fragment and the 1.7 EcoRI fragment, were subcloned into pTZ18R and pTZ19R respectively, in both orientations, yielding pEMS300A, pEMS300B, pEMS301A and pEMS301B. Sets of ordered deletions were created for each plasmid using Exonuclease III and SI nuclease, followed by treatment with Klenow enzyme and blunt-end ligation with T4-DNA ligase, according to the Pharmacia protocol. The region between the $S a I$ and the EcoRI fragments was sequenced using a clone containing the $0.7 \mathrm{~kb} E c o$ RI fragment, which overlaps the $2.0 \mathrm{~kb}$ Sall fragment
(Fig. 1). This fragment was cloned into pTZ19R. The $5.2 \mathrm{~kb}$ Sall fragment (Fig. 1), overlapping the $1.7 \mathrm{~kb}$ EcoRI fragment, was cloned into pTZ18R and sequenced in the opposite direction to the smaller EcoRI fragment. A total of 56 clones covering both directions were sequenced by the chain termination method using deoxyadenosine $5^{\prime}-\alpha-$ $\left[{ }^{35}\right.$ S $]$ thiotriphosphate $\left(\left[\alpha^{35} \mathrm{~S}\right] \mathrm{dATP}\right)$ (Bankier et al., 1987). Regions with severe band compression (high GC) were resolved using 7deazaguanosine triphosphate instead of dGTP. Primary sequences were fed into a VAX computer, edited using the DButil program and analysed using the Analyseq (Staden, 1982, 1984) and UWGCG programs (Devereux et al., 1984). The best alignment of the amino acid sequences was determined using the Clustal program (Higgins \& Sharp, 1988).

Cloning and molecular biology methods. All enzymes were obtained from commercial sources and used according to the manufacturers' instructions. Transformation, DNA purification from agarose gels, electrophoresis and single-strand DNA purification for enzymic sequencing were done as described by Maniatis et al. (1982) and Bankier et al. (1987).

\section{Results}

\section{$A$ nif $A$-like gene is present in $H$. seropedicae}

Plasmid pEMS1 contains a $30 \mathrm{~kb}$ DNA fragment, and was isolated from a genomic library of $H$. seropedicae strain Z78 constructed in the cosmid pVK102 (Souza et al., 1991). This recombinant plasmid was capable of complementing the nif $A$-like mutant (FP10) of Azospirillum brasilense. Plasmid pEMS101 was constructed by deleting the $21 \mathrm{~kb} \mathrm{BamHI}$ fragment from pEMS1 and is also capable of complementing FP10 (Souza et al., 1991).

To locate and confirm the presence of the nif $A$-like gene on plasmid pEMS101, hybridization experiments were performed using the following two probes derived from pMC71A (Buchanan-Wollaston et al., 1981): (a) a $3 \mathrm{~kb}$ SalI fragment containing the complete nif $A$ and 
(a)

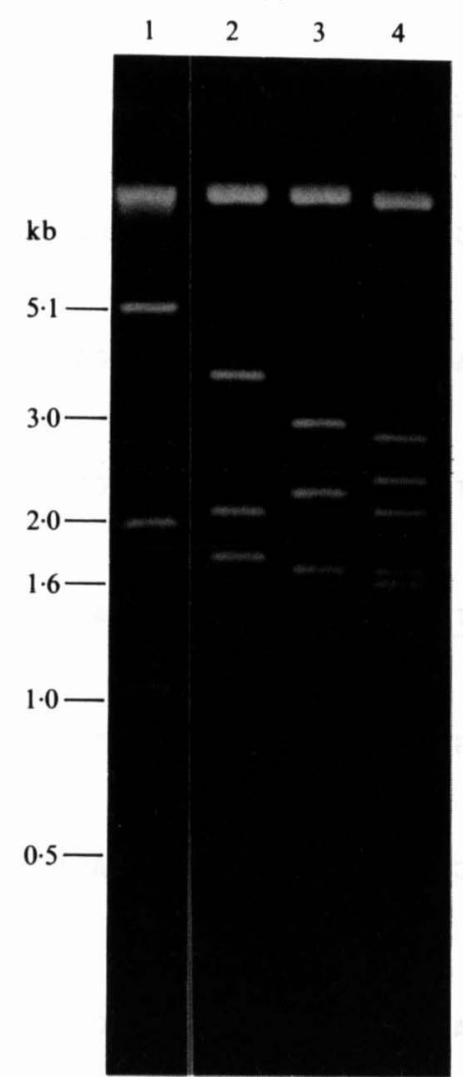

(b)

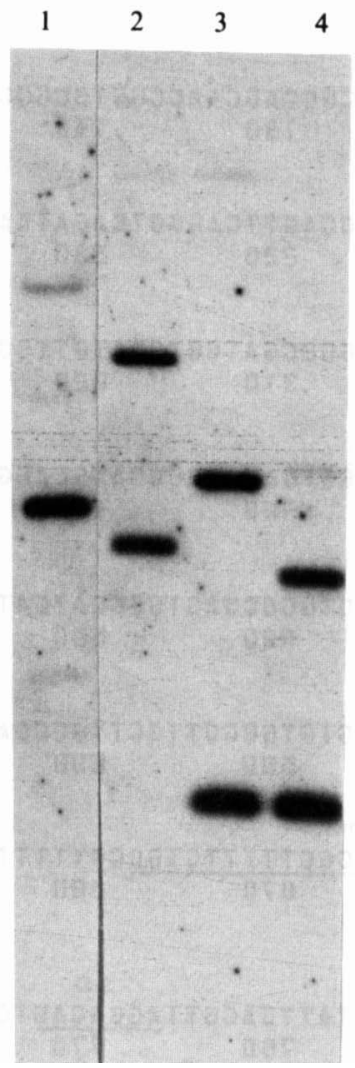

(c)

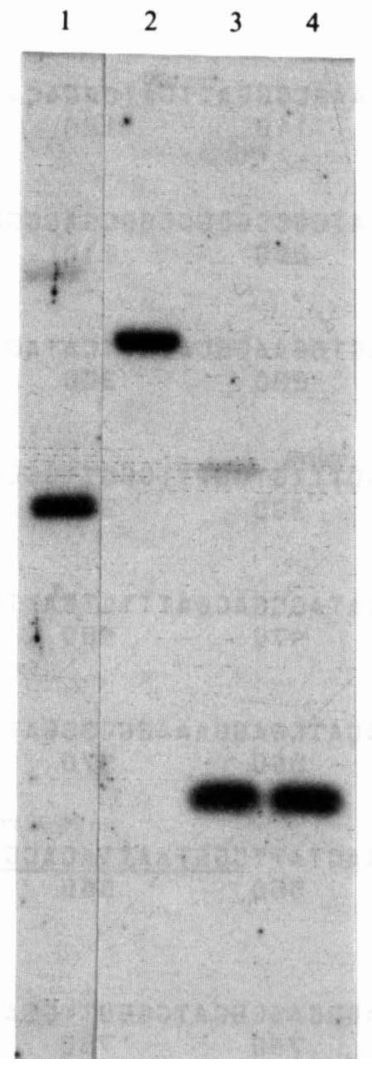

Fig. 2. Location of the nif $A$-like gene of $H$. seropedicae in pEMS101. (a) Restriction pattern of pEMS101 digested with: (1) SalI, (2) Pst I, (3) BglII, and (4) PstI plus BglII. (b) Autoradiogram showing hybridization of restricted pEMSI01 to the $3 \mathrm{~kb} S a l \mathrm{I}$ fragment from pMC71 A containing nif $A$ and part of the nif $B$ of $K$. pneumoniae (probe A). (c) Autoradiogram showing hybridization of pEMS101 to the $1.4 \mathrm{~kb}$ NruI fragment from pMC71A containing only the nif $A$ of $K$. pneumoniae (probe B).

part of nifB and nifL from $K$. pneumoniae (probe A); and (b) a $1.4 \mathrm{~kb} \mathrm{NruI}$ fragment containing $69 \mathrm{bp}$ of nifL and most of the nif $A$ from $K$. pneumoniae (probe B). The restriction pattern of pEMS101 cleaved with SalI, PstI, $B g l \mathrm{II}$ and $P s t \mathrm{I} / B g l \mathrm{II}$ is shown in Fig. 2(a). Hybridization of these restriction fragments with probe $A$ and probe $B$ are shown in Fig. 2(b) and 2(c), respectively. The strong hybridization signals observed with both probes, although under low stringency conditions, indicated the presence of a nif $A$-like gene in $H$. seropedicae. The nif $A$ specific probe (probe B) did not hybridize to the $1.7 \mathrm{~kb}$ Pst I, $2.3 \mathrm{~kb} B g I I \mathrm{II}$ or $1.6 \mathrm{~kb}$ Pst $\mathrm{I} / B g I \mathrm{II}$ fragments. This negative result suggested the additional presence of nif $B$ or $n i f L$ on pEMS101, adjacent to the putative nif $A$ gene in $H$. seropedicae. Hybridization of probes $\mathrm{A}$ and $\mathrm{B}$ to a single $2.0 \mathrm{~kb} S a l$ fragment (Fig. $2 b, c$ ) positioned the majority of the nif $A$-like gene of $H$. seropedicae in this fragment. The absence of hybridization of the $1.7 \mathrm{~kb}$ PstI fragment to probe B (Fig. $2 c$ ) suggested that the nif $A$-like gene is restricted to the $1.1 \mathrm{~kb}$ Sall/PstI fragment (compare Fig. 1 with Fig. 2).

Nucleotide sequence of the nif A-like gene from H. seropedicae

The DNA region most likely to contain the entire nif $A$ like gene from $H$. seropedicae, as determined by hybridization comprises a $2.0 \mathrm{~kb}$ SalI fragment, part of a $1.7 \mathrm{~kb} E c o \mathrm{RI}$ fragment and an interconnecting region (Fig. 1). These fragments were sequenced in both directions and the final sequence was found to be 4037 bp long, 3287 bp of which are shown in Fig. 3. Analysis of this sequence by a base positional method (Staden, 1984) indicated the presence of two potential coding regions: a complete open reading frame (ORF) and the $\mathrm{N}$-terminus of a $3^{\prime} \mathrm{ORF}$. Hybridization and genetic complementation studies (Souza et al., 1991) suggest that the complete ORF corresponds to the $H$. 


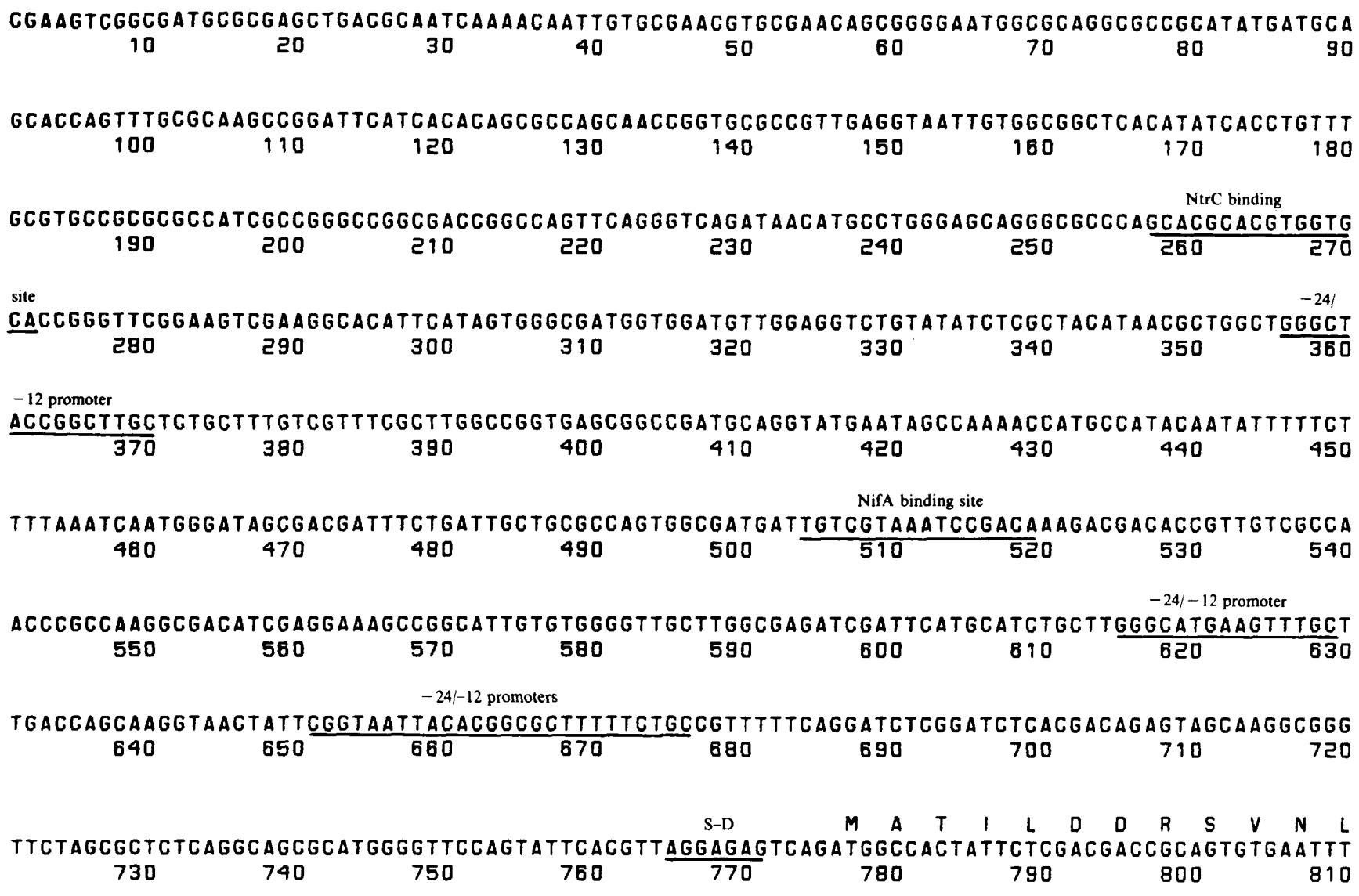

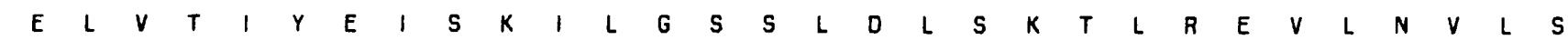
AGAACTCGTAACGATTTACGAGATCAGCAAGATATTGGGTTCATCGCTGGATCTATÇCAAGACCTTGCGCGAAGTCCTCAACGTCCTCTC

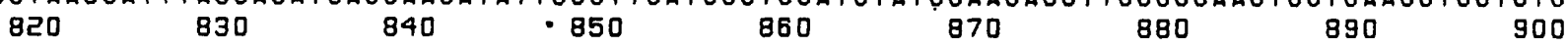

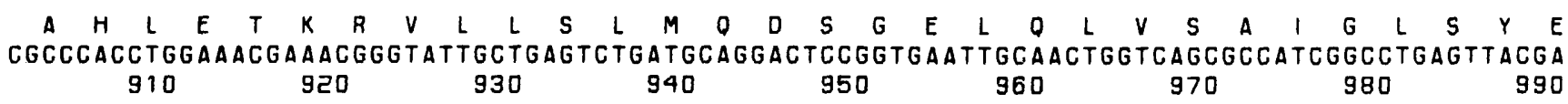

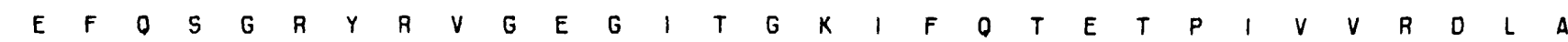
AGAATTCCAGAGTGGCAGATACCGGGTCGGCGAGGGCATCACCGGCAAGATCTTCCAGACGGAAACTCCCATCGTGGTGCGCGACTTGGC

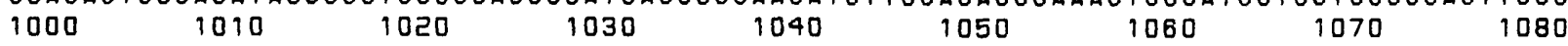

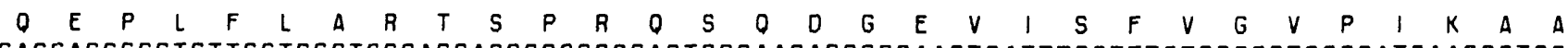
CCAGGAGCCGCTGTTCCTGGCTCGCACCAGCCCGCGCCAGTCGCAAGACGGGGAAGTCATTTCCTTTGTGGGCGTGCCGATCAAGGCTGC

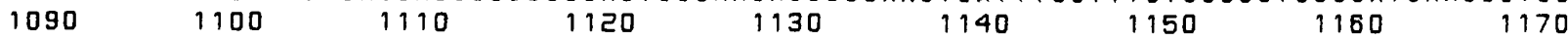

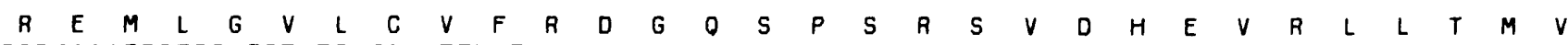
CCGTGAAATGCTGGGTGTGTTGTGCGTTTTTCGGGATGGACAATCGCCCTCGCGTAGTGTCGACCATGAGGTGCGCCTGCTGACCATGGT

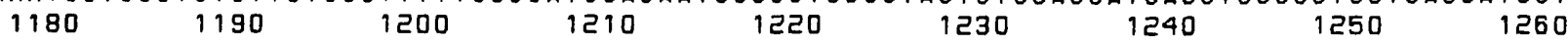

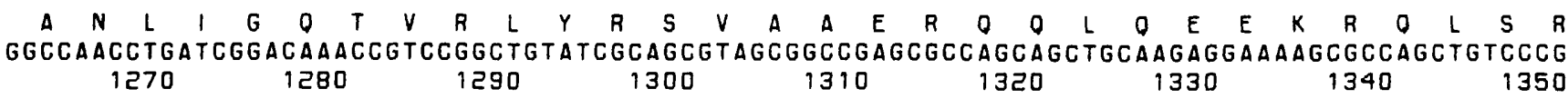

Fig. 3 (continued on the following two pages). Nucleotide sequence of the nif $A$-like region of $H$. seropedicae. The putative nif regulatory sequences and the potential ribosome binding sites are underlined. The sequence encoding NifA starts at position 776 and stops at position 2404 while the sequence encoding NifB starts at 2797 . The stop codon of the nif $A$ gene is indicated by an asterisk. 


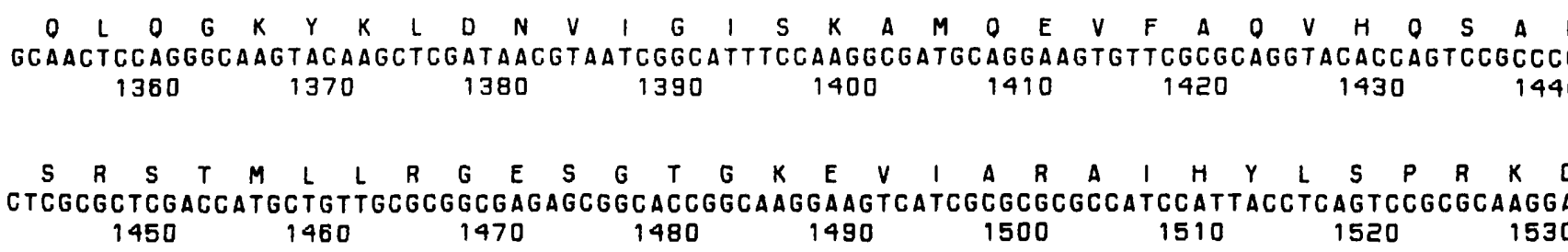

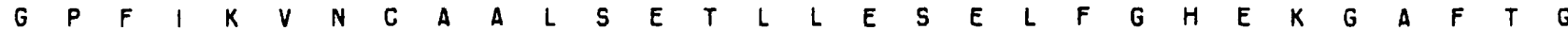
TGGGCCATTCATCAAGGTCAACTGTGCGGCCTTGTCGGAAACCTTGCTGGAATCCGAATTGTTTGGCCACGAGAAGGGCGCCTTCACCGG $\begin{array}{llllllll}1540 & 1550 & 1580 & 1570 & 1580 & 1590 & 1600 & 1810\end{array}$

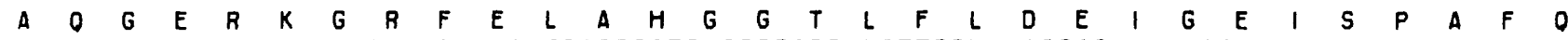
GGCCCAGGGTGAACGCAAGGGGCGTTTCGAACTCGCCCATGGCGGCACCTTGTTCCTCGACGAGATCGGCGAGATCTCGCCGGCCTTCCA $\begin{array}{llllllll}1630 & 1640 & 1650 & 1660 & 1670 & 1680 & 1690 & 1700\end{array}$

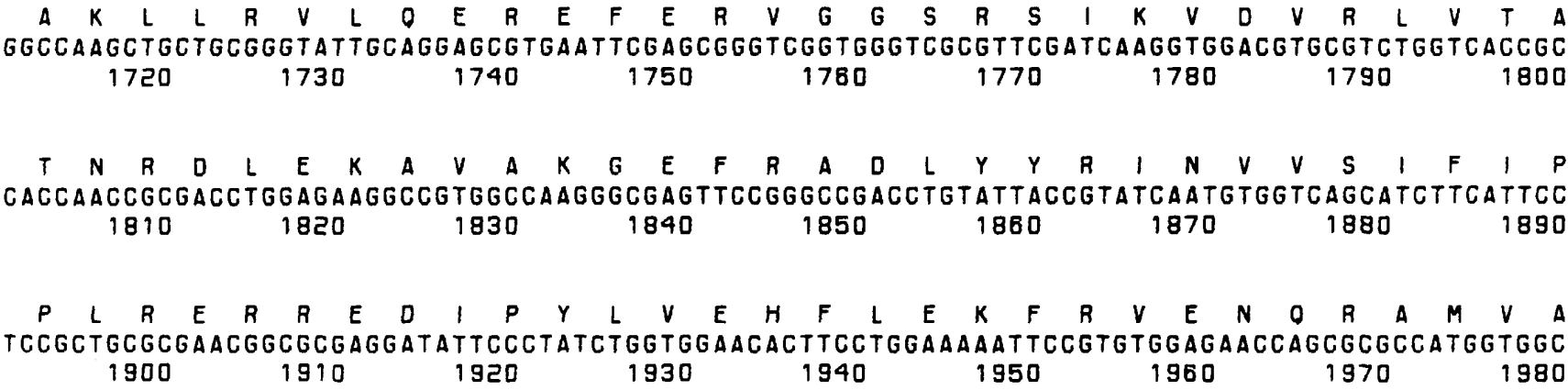

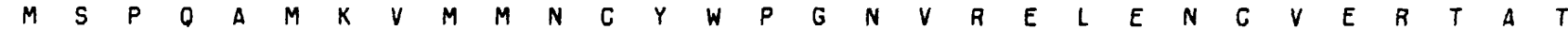
CATGTCACCGCAGGCCATGAAGGTCATGATGAATTGCTACTGGCCGGGCAATGTACGGGAACTGGAAAATTGTGTCGAGCGTACTGCCAC

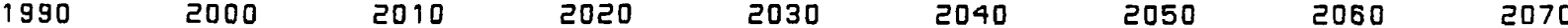

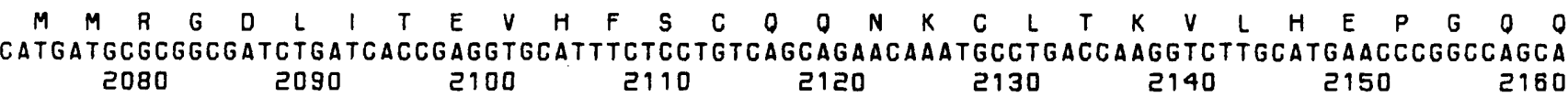

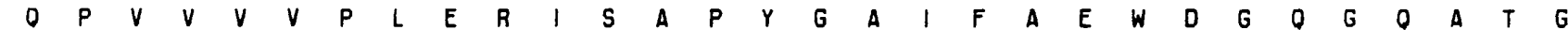
GCAACCGGTCGTGGTGGTGCCGCTGGAGCGCATATCCGCGCCATACGGCGCCATCTTCGCCGAGTGGGATGGCCAAGGACAAGCCACTGG $\begin{array}{llllllll}2170 & 2180 & 2190 & 2200 & 2210 & 2220 & 2230 & 2240\end{array}$

$\begin{array}{lllllllllllllllllllllllllllllllllll}A & A & P & P & T & S & E & R & E & R & L & I & W & A & M & E & O & C & G & W & V & 0 & A & K & A & A & R & A & L & N\end{array}$ CGCCGCGCCCCCGACCTCCGAACGCGAACGTCTTATCTGGGCCATGGAGCAATGTGGCTGGGTGCAAGCCAAGGCAGCCCGCGCACTCAA

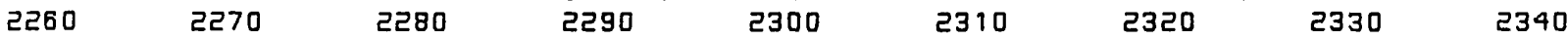

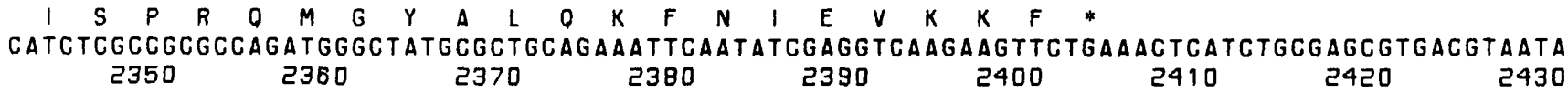

CGCTGCCAGATCCAAAGTCTTTTTCTCATTGCCGTCCTCGCCCTGCGCGCGCGGTCTCTTCGGCGTCGCGCCAGCCGGTTGTATTGATGG

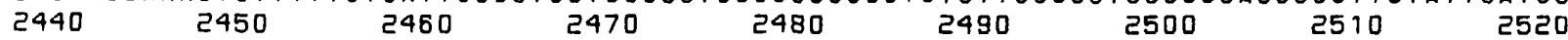

ATTCCCCGGCTCGGCACGTCCTCGCATTCTCCTTCTCCTTCTCCACTGCGTCAGGCTCATTGCGGCGCGCTCAATTGCAGGCGCCGGCCC

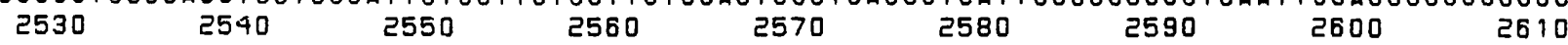

NifA binding site

NifA binding site

GTGCTGCATTGTCGTGTTCATGACAAGCGCCACCCACAATGTATCGCCGATTGTCGCTATCCTCACATCGCCGTACGACGCAATTCTCCG 2620

2630

2640

2650

2560

2670

2680

2690

2700 


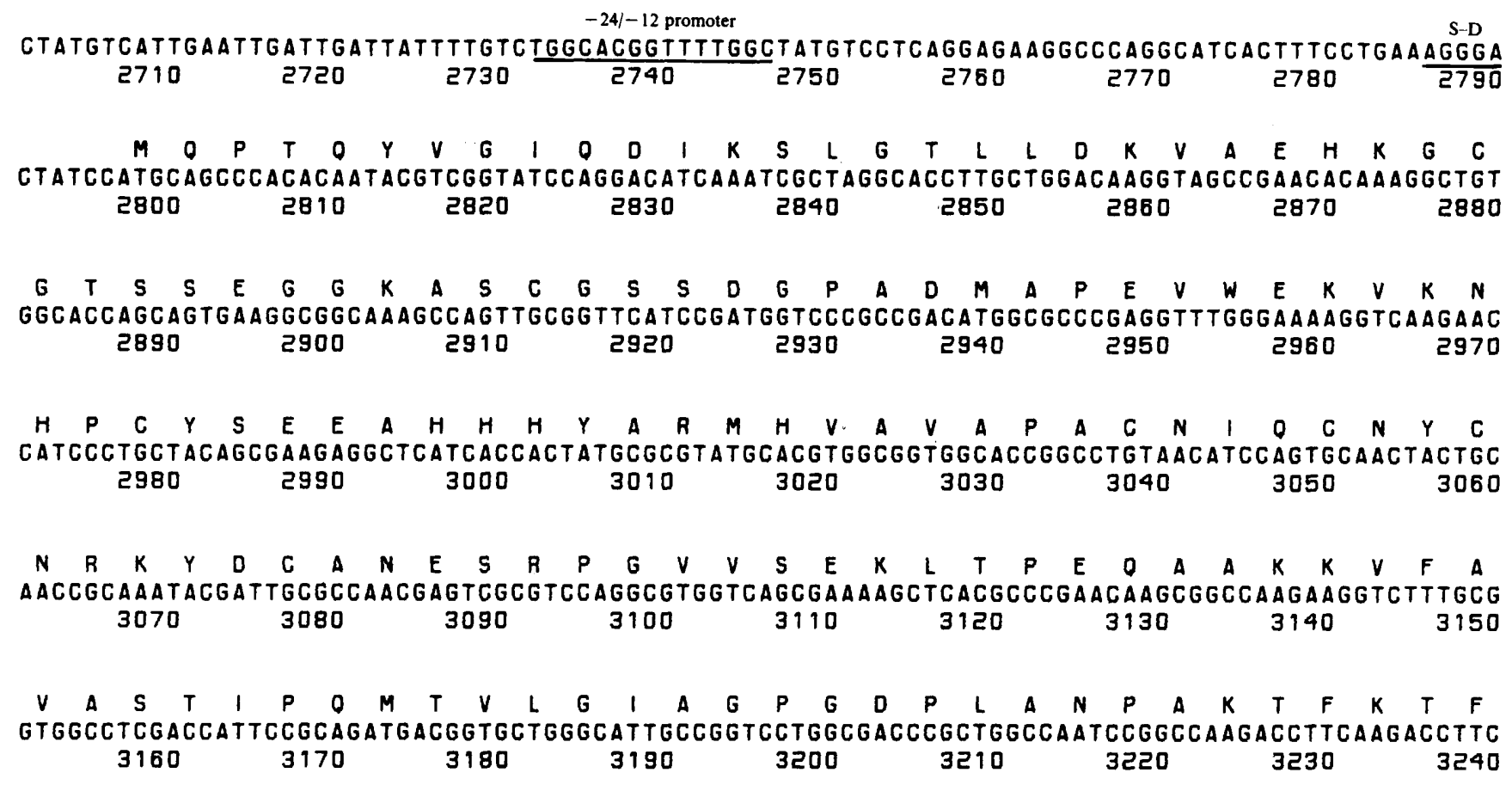

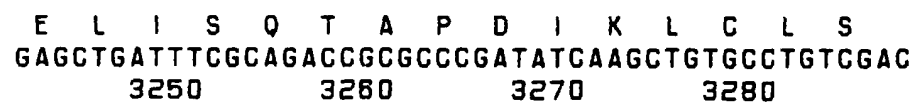

seropedicae nif $A$-like gene. This ORF comprises 1629 nucleotides, contains only one in-frame methionine initiation codon at position 776 , terminates at position 2404 and codes for a protein of 542 amino acid residues $\left(M_{\mathrm{r}} 60880\right)$. A putative Shine-Dalgarno sequence was found $4 \mathrm{bp}$ from the translation initiation codon (AUG) (Fig. 3).

The $H$. seropedicae NifA-like protein deduced from the nucleotide sequence was compared to the inferred amino acid sequences of NifA proteins from $K$. pneumoniae (Buikema et al., 1985; Drummond et al., 1986), R. meliloti (Buikema et al., 1985), R. leguminosarum (Grönger et al., 1987) and Azorhizobium caulinodans (Nees et al., 1988) (Fig. 4). The homology in the Nterminal region of all proteins, domains $\mathrm{A}$ and $\mathrm{C}$ as defined by Drummond et al. (1986), was very poor: there were only seven identical amino acid residues and several gaps had to be introduced to reveal similarity. However, in the central domain (domain D) and in the C-terminal domain (domain E) extensive similarity was found. Overall, the NifA protein of $H$. seropedicae showed the highest degree of homology with that of Azorhizobium caulinodans (47\%) and the lowest with that of $K$. pneumoniae $(38 \%)$.

Finally, the $H$. seropedicae amino acid sequence also contains a conserved interdomain, between domain D and domain E (Fig. 4), similar to that present in NifA proteins of Rhizobium species (Buikema et al., 1985; Grönger et al., 1987), Bradyrhizobium japonicum (Fischer et al., 1988), Azorhizobium caulinodans (Nees et al., 1988) and Rhodobacter capsulatus (Masepohl et al., 1988), but which is absent from $K$. pneumoniae or Aztobacter vinelandii (Bennett et al., 1988). Although these linking regions are not highly homologous, two cysteine residues, separated by four residues, are conserved and there are also several conservative substitutions.

\section{Regulatory sequences}

The promoter region of the nif $A$-like gene of $H$. seropedicae is complex. Three potential $-24 /-12$ promoters occur at about $110 \mathrm{bp} 5^{\prime}$ from the translation initiation site: GGGCATGAAGTTTGCT, at position 615; CGGCGCTTTTTCTGCC, at position 662; and CGGTAATTACACGGCG, at position 651. Of these three sequences, the first is the best match to the consensus sequence and the third is the poorest match and least likely to constitute a functional $-24 /-12$ promoter (Fig. 3 and Fig. $5 b$ ). Furthermore, a putative NifA-binding site (TGTCGTAAATCCGACA, at 
$A$

HsNifA AcNifA RINifA RmNifA KpNifA

Consensus

HsNifA AcNifA RINifA

RmNifA

KpNifA

Consensus

HsNifA AcNifA RINifA RmNifA KpNifA

Consensus

HsNifA AcNifA RINifA RmNifA KpNifA

Consensus

HsNifA AcNifA RINifA RmNifA KpNifA

Consensus

HsNifA AcNifA RINifA RmNifA KpNifA Consensus

HsNifA AcNifa RINifA RmNifA KpNifA Consensus
MATILDDR-- - MTDAFOVRVPRVSSSTAGDI AASS I TTRGALPRPGGMPVSMSRGTSPEVALIGVYEISK I MIKM-KMIH--

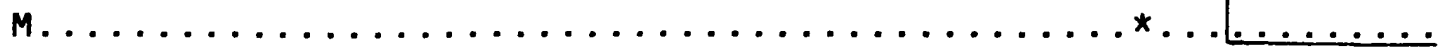
LGSSLDLSKTLREVLNVLSAHLETKAVLISLMOOSGELOLVSAIGLSYEEF QSG----RY LTAPRRLEVTLANVVNVLSSML OMRHGMICI LDSEGDPDMVATTGWTPEMAGOI----RA LISSFPLDNLLKAAMNALVEHLRLRDGG IV IHGSGGEPW-INVRA-----PIGD----DV LMAPTRLETTLNNFVNTLSLILRMRRGGLE I PASEGETK-ITAATRNSGSPSAA---DY - - - KTLOEVLSVLHNDAFMOHGMI CLYDSOOE ILSIEALOOTEDOTLPGSTQIRY

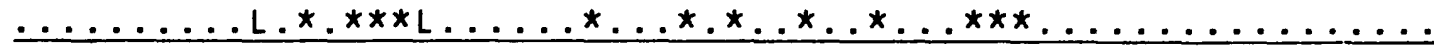

RVGEG ITGK IFOTETP IVVRDLAOEPLFLARTSPROSODGEVISFVGVPIKAAR-EMLGV HVPOKA I DOIVATOMPLVVQDVTADPLFAGHEDLFGPPEEATVSFIGVPIKADH-HVMGT RSRSLT IEOADA INR-VIASG--EKHFGKNSV---TVPKAA I DOVMTAGR-LVVPDVCNSELFKDOI KWRG I---GPTAF I AAAVEVDH-ETGGM RPGEGLVGTVLAOGOSLVLPRVADDORFLDRLSLYDYD----LPF I AVPLMGPHSRPIGV

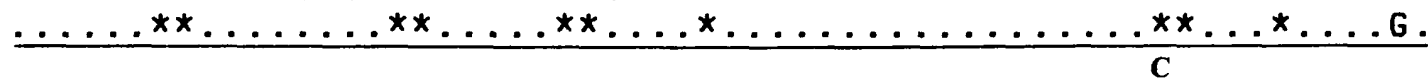
LCV--FRDGQSPSRSVDHEVRLLTMVANL IGOTVRLYRSVA AEROQL OEEKROLSROLQG LS I DR I WDGTARFR-FDEDVRFLTMVANL VGOTVRLHKL VASDRDRL I AOTHRLEKALRE LWI DF---AOKSG---AODESL LAMI AVLIGLTCORDRELICSDGGSVAEE----OQAGOI LWFEC---AEESDYDYEEEVHF LSMAANL AGRA IRLHRT ISRRERTFAEE---DOEOQN LAAHAMAROEERLPACT-- RFLETVANL IAOT IRL------ MILPTSAAQAPQOS

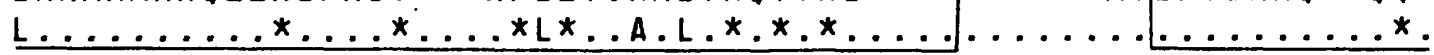
D KYKLDN---------FVIGISKAMOEVFAOVHOSAPSRSTMLLRGESGTGKEVIARA EKSGAEPEVAEAANGSAMG I VGDSPLVKRL I ATAOVVARSNSTVLLRGESGTGKELFARA PK I KPKPHPTQ--LDK I DW I VGESPALKRVLATTK I VAATNSAVLLRGESGTGKECFARA SRDEOSOSSARORLLKNDG I I GESTALMTAVDTAKVMAETNS I VLLRGETGTGKECFAKL PRIERPRACTPSAGFGLENMVGKSPAMROIMDIIROVSRWDTTVLVRGESGTGKELIANA

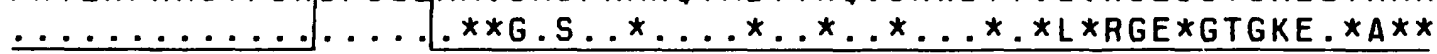

IHYLSPRKDGPF IKVNCAALSETLLESELFGHEKGAF TGAOGERKGRFELAHGGTLFLDE I HELSPRKGKPFVKVNCAALPESVLESELFGHEKGAFTGALNMROGRFELAHGGTLFLDE I HALS IRKSKAF I KLNCAALSETVLESELFGHEKGAFTGALLORAGRFELANGGTLLLDE I HOHSTROKKPF I KFNCPALSESLLESELFGHEKGAFTGA I AORVGRFESANGGTLLLDE I HHNSPRAAAAFVKFNCAALPONLLESELFGHEKGAFTGAVRORKGRFELADGGTLFLDE IH..S.R...*F*K.NC*AL****LESELFGHEKGAFTGA...R.GRFE.A*GGTL*LDE

IGEISPAFOAKLLRVLQEREFERVGGSRS IKVDVRLVTATNRDLEKAVAKGEFRADLYYR IGE I TPAFOAKLLRVLOEGEFERVGGNRTLKVDVRLVCATNKNLEEAVSKGEFRADLYYR I GDVSPQFOAKLLRVLQEGEFERLGGTKTLKVDVRV I CATNKNLEVAVLRGEFRADLYYR I GE I PPAFOAKLLRV I OEGEFERVGGTKTLKVDVRL IFATNKDLEMAVONGEFREDLYYR IGESSASF OAKLLRI LOEGEMERVGGDETLRVNVR I IAATNRHLEEEVRLGHFREDLYYR $1 G * . * * . F Q A K L L R * * Q E . E * E R * G G * . * * * V * V R * * . A R T * * L E . * V . . G * F R * D L Y Y R$

Fig. 4 (continued on the following page). Alignment of the deduced amino acid sequence from the $H$. seropedicae NifA-like protein relative to other homologous NifA proteins. HsNifA, $H$. seropedicae NifA; AcNifA, Azorhizobium caulinodans NifA; RINifA, $R$. leguminosarum NifA; RmNifA, $R$. meliloti NifA; and KpNifA, $K$. pneumoniae NifA. The consensus sequence shown required the simultaneous matching of amino acids in all five proteins. Conservative substitutions (Higgins \& Sharp, 1988) are indicated by asterisks, and mismatches are indicated by dots. Domains A, C, D and E are boxed as originally proposed by Drummond $e$ t al. (1986), although the homology in the $\mathrm{N}$-terminus shared among the five proteins is not sufficiently high to define domains $\mathrm{A}$ and $\mathrm{C}$. The interdomain linker (I) is denoted by a horizontal bar and the conserved cysteine residues by the symbol + . 


\begin{tabular}{|c|c|}
\hline HsNifA & INVVS IF I PPLRERREDIPYL \\
\hline AcNifA & IHVVPLILPPLRERPGDIPKL \\
\hline RINifA & INVVP I I LPPLRORDGD ISLL \\
\hline RmNifA & ISGVPL I LPPLRHRDGOIP \\
\hline $\mathrm{KpNifA}$ & LNVMP I ALPPLREROED I A \\
\hline \multirow[t]{2}{*}{ Consensus } & $\star \ldots . * \star \star \star * * P P L R * R, * 0 \mid *$ \\
\hline & + \\
\hline HsNifA & ENCVERTATMMRGDL ITEVH \\
\hline AcNifA & ENC I RRTATLAHDAV ITPHD \\
\hline RINifA & DNGVORTATLASSNTITSSD \\
\hline RmNifA & ENCVRRTATLARSKTITSSD \\
\hline KpNifA & ENCLERSAVLSESGL \\
\hline Consensus & $\star N G \star . R * A * \star \ldots \star \ldots I$. \\
\hline HsNifA & YG \\
\hline AcNifA & LATAAPAAASPAPAADSL \\
\hline RINifA & CAHAGT--- \\
\hline RmNifA & - ANDVP \\
\hline KpNifA & -DRDVILFNHRDNPPKALAS \\
\hline Consensus & *.. \\
\hline HsNifA & ISPRQMGYALQKFNIEVKKF \\
\hline AcNifA & LTPRQVGYALRKYDIDIKAF \\
\hline RINifA & KTPROVGYALRRHR I DVKKE \\
\hline RmNifA & KTPRQVGYALRRHGVDVRKL \\
\hline $\mathrm{KpNifA}$ & MTPROVAYRI Q|IMDI TMPRL \\
\hline Consensus & $. * P R Q * * Y . * * \ldots * \ldots * * . *$. \\
\hline
\end{tabular}

position 504) about $110 \mathrm{bp} 5^{\prime}$ from the $-24 /-12$ motif at 615 , suggests this region as a likely promoter (Fig. 3 and Fig. $5 b$ ). Another $-24 /-12$ promoter sequence (GGGCTACCGGCTTGCT, at position 356) and a NtrC-binding site (GCACGCACGTGGTGCAC, at 257) are located further $5^{\prime}$ to the initiation site (Fig. 3 and Fig. 5a).

The 'anaerobox' and the integration host factor $(\mathrm{IHF})$ site

There are two additional features which may have a role in the control of the expression of $H$. seropedicae nif $A$. First, a potential 'anaerobox' sequence was identified at position 1538 (TTCATCAAGGTCAA), 3' from the translation initiation site. This structure has two mismatches (underlined) with respect to the 'anaerobox' consensus sequence (TTGATNNNNATCAA) (Nees et al., 1988). A putative repressive function has been ascribed to an 'anaerobox' in a coding region (Nees et al., 1988).

Secondly, starting 49 bp $5^{\prime}$ from the putative NifAbinding site in the $H$. seropedicae nif $A$-like promoter (position 455) is the sequence AATCAATGGGATA which differs from the IHF consensus sequence (WATCAANNNNTTR, where $\mathrm{W}=\mathrm{A}, \mathrm{T}$, and $\mathrm{R}=\mathrm{A}$ or $\mathrm{G}$ ) in only one conserved thymine residue (underlined) (Yang \& Nash, 1989; Goodrich et al., 1990). This factor has the ability to introduce bends in DNA (Yang \& Nash, 1989), presumably to assist contact between upstream activators and the sigma factor and is normally located between the $5^{\prime}$ activator binding site and the promoter.

\section{The nif $B$-like sequence}

The N-terminal of another ORF was found 3' from the nif $A$ gene. The protein deduced from this sequenced region spans the first 162 amino acid residues, starting at position 2797 (Fig. 3). Hybridization studies had previously indicated the presence of sequences homologous to either nifB or nif $L$ in this region of pEMS101 (Fig. 2). Comparison of the partial amino acid sequence, deduced from this ORF, with the NifB proteins from Azotobacter vinelandii (Joerger \& Bishop, 
(a) NtrC-activated promoters

UAS -24 -12

KpglnA TGCACTATATTGGTGCA-----TTGGCACAGATTTCGCT

KpnifL TGCACTACCGCGGCGCA-----AGGGCGCACGGTTTGCA

HsnifA AGCACGCACGTGGTGCA-----TGGGCTACCGGCTTGCT

Consensus $\dagger$ GCACY-N 5 -GGTGCA---- NTGGCRCR-N $4-$ TTGC $_{T}^{A}$

(b) Putative NifA upstream activating sequence (UAS) in nifA promoters

\begin{tabular}{|c|c|c|}
\hline & UAS & -24 \\
\hline AcnifA & \multicolumn{2}{|c|}{ GGTTTCCATTATAACA----AGGCTGATCCCTCGCA } \\
\hline KpnifL $\ddagger$ & \multicolumn{2}{|r|}{ GGGCGCACGGTTTGCA-- -TGT-N/10 } \\
\hline HsnifA & \multicolumn{2}{|c|}{ TGTCGTAAATCCGACA----GGGGATGAAGTTTGCT } \\
\hline onsensus $\dagger$ & $T G T-N_{1}$ & -TGGYAYR-N $4-$ TTGC $_{T}^{A}$ \\
\hline
\end{tabular}

(c) Putative NifA upstream activating sequence (UAS) in nifB promoters

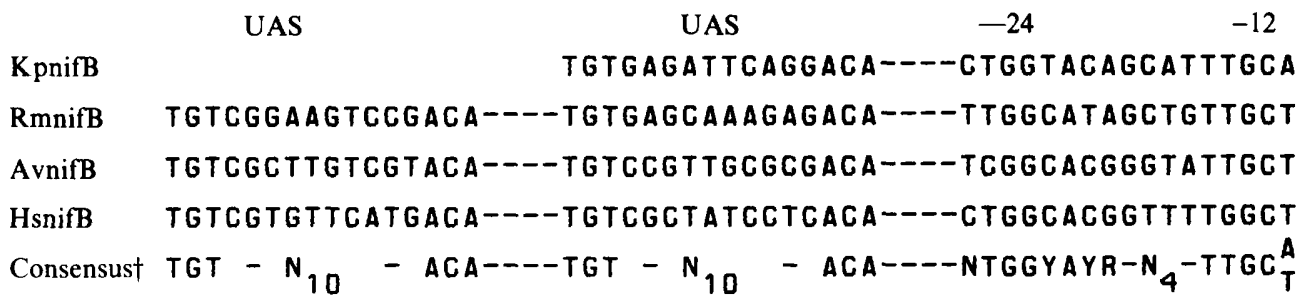

Fig. 5. Comparison of $H$. seropedicae nif $A$ and nif $B$ promoters with NtrC- and NifA-activating promoters of $K$. pneumoniae (Kp), $R$. meliloti ( $\mathrm{Rm})$, Azotobacter vinelandii (Av) and Azorhizobium caulinodans (Ac).

$\dagger$ Consensus sequences are according to Dixon (1988).

$\ddagger$ The NifA binding site in the nifL promoter of $K$. pneumoniae is located downstream from the transcription initiation site (Drummond et al., 1983).

\begin{tabular}{|c|c|}
\hline $\begin{array}{l}\text { HsNifB } \\
\text { BjNifB } \\
\text { AvNifB }\end{array}$ & $\begin{array}{l}\text { MOPTOYVG I QDIKSLGTLLOKVAEHKGCGTSSEGGKAS-CGSSDGP-ADMAPEVWEKVKN } \\
\text { MO-- } \\
\text { ME--- }\end{array}$ \\
\hline Consensus & 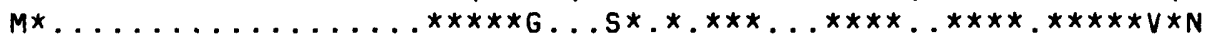 \\
\hline $\begin{array}{l}\text { HsNifB } \\
\text { BjNifB } \\
\text { AvNifB } \\
\text { Consensus }\end{array}$ & 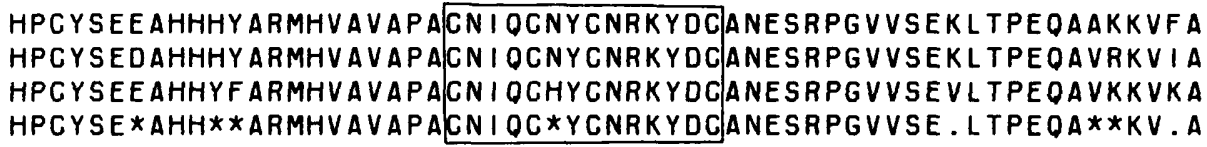 \\
\hline $\begin{array}{l}\text { HsNifB } \\
\text { BjNifB } \\
\text { AvNifB } \\
\text { Consensus }\end{array}$ & 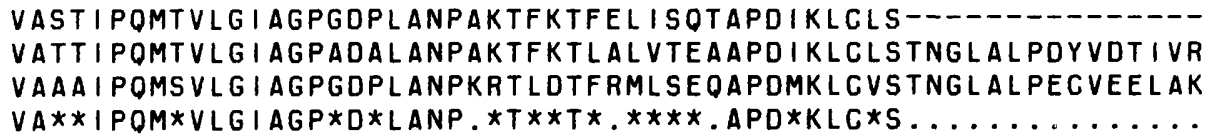 \\
\hline
\end{tabular}

Fig. 6. Alignment of the deduced $\mathrm{N}$-terminus of the Nif B protein according to amino acid homology. HsNif B, H. seropedicae $\mathrm{Nif}$ B; AvNif B, Azotobacter vinelandii $\mathrm{NifB}$; and $\mathrm{BjNifB}, B$. japonicum $\mathrm{Nif}$. The consensus sequence shown required the simultaneous matching of amino acids in all three proteins. Conservative substitutions (Higgins \& Sharp, 1988) are indicated by asterisks, and mismatches are indicated by dots. The conserved cysteine cluster is boxed.

1988) and Bradyrhizobium japonicum (Noti et al., 1986) showed extensive homology (Fig. 6). A cluster of cysteine residues (cys- $\mathrm{X}_{3}$-cys- $\mathrm{X}_{2}$-cys- $\mathrm{X}_{5}$-cys), characteristic of Nif B proteins (Buikema et al., 1987) was found between residues 80 and 94 , and most (approximately $90 \%$ ) of the 20 amino acid residues spanning each side of this cluster were found to be conserved in the $H$. seropedicae NifB-like protein (Fig. 6). A possible $-24 /-12$ pro- 
moter and two potential NifA-binding sites (TGTCGTGTTCATGACA, at position 2620 and TGTCGCTATCCTCACA, at position 2661) were identified $5^{\prime}$ from the initiation codon of the $H$. seropedicae nif $B$-like gene (Fig. 3 and Fig. $5 c$ ). A possible IHF-binding motif occurs at position 2708-2720 (Fig. 3).

\section{Discussion}

Our results show that $H$. seropedicae contains nif $A$ - and nif $B$-like genes which code for proteins similar in structure to NifA and Nif B proteins from other species. As expected, the NifA homology was confined to the $\mathrm{C}$-terminal half of the proteins. The degree of homology of domains $\mathrm{D}$ (central domain) and $\mathrm{E}$ (DNA-binding site) of $\boldsymbol{H}$. seropedicae was higher with the respective domains of Azorhizobium caulinodans and rhizobia, than with those of $H$. seropedicae and $K$. pneumoniae. Our results also indicate that the nif $A$-like gene of $H$. seropedicae may be regulated by $\mathrm{NtrC}, \mathrm{NifA}$ and $\mathrm{RpoN}$, as is nif $A$ in $K$. pneumoniae (Merrick, 1983; Drummond et al., 1983).

A conserved interdomain is present in the NifA proteins from $R$. meliloti, B. japonicum, $R$. leguminosarum, Azorhizobium caulinodans, Rhod. capsulatus and $\boldsymbol{H}$. seropedicae, but is absent from those of $K$. pneumoniae and Azotobacter vinelandii. Two highly conserved cysteine residues are found in this region which, together with two other cysteine residues located at the end of the central domain (Fig. 4), have been proposed to be part of a metal-binding site which could act as a sensor for oxygen. Under low oxygen levels the bound metal would be reduced, thus stabilizing NifA in an active form, whereas at high oxygen concentrations the bound metal would be oxidized, destabilizing NifA and preventing activation of nif transcription (Fischer et al., 1988). In $B$. japonicum the four cysteine residues are essential for NifA function and metal chelators prevent $B$. japonicum NifA from activating nif $D$ transcription (Fisher et al., 1988). Metal chelators have no effect on transcription activation by NifA of $K$. pneumoniae. Recently, it has been demonstrated that the NifA from $B$. japonicum is indeed sensitive to oxygen whereas $K$. pneumoniae NifA, which lacks this interdomain, is not (Fischer \& Hennecke, 1987). The presence of this interdomain in the NifA-like protein of $H$. seropedicae suggests that its activity may be controlled by the prevailing oxygen levels.

The arrangement of a $-24 /-12$ promoter element and a NifA-binding site about $100 \mathrm{bp} 5^{\prime}$ in the nif $A$-like gene of $\boldsymbol{H}$. seropedicae is typical of nif promoters which are activated by NifA protein and require RpoN as $\sigma$-factor (Gussin et al., 1986; Dixon, 1988). Most promoters of nif $A$ genes do not contain a prominent NifA upstream activating sequence. However, a potential NifA-binding site was found $5^{\prime}$ from the nif $A$ of Azorhizobium caulinodans (Nees et al., 1988), where it may act as a negative autoregulator under non-symbiotic $\mathrm{N}_{2}$-fixing conditions (de Bruijn et al., 1988). Furthermore, a putative NifA-binding site was also found in the intercistronic region of the fixRnif $A$ operon from $B$. japonicum, which is autoactivated by the NifA protein (Thöny et al., 1989). The presence of a $-24 /-12$ promoter element and a correct spacing in respect to the upstream activating sequence, favour the idea that NifA may autogenously activate transcription of the nif $A$ gene in $H$. seropedicae.

An NtrC-binding site and a $-24 /-12$ promoter sequence are located $505 \mathrm{bp}$ and $407 \mathrm{bp} 5^{\prime}$ from the putative initiation codon of the $H$. seropedicae nif $A$ gene, suggesting a possible role for $\mathrm{NtrC}$ in nif $A$ transcription.

The IHF-binding site has been reported in other nif promoters: it occurs in the nif $H$ promoter region between the NifA-binding site and the promoter (Santero et al., 1989) and the IHF protein enhances NifA-mediated expression of nifH in vitro (Hoover et al., 1990). The nif $U$ promoter, on the other hand, contains multiple NifAbinding sites, one of which abuts the IHF-binding site at which NifA and the IHF compete for binding, thus inhibiting nif $U$ transcription (Cannon et al., 1990). The proximity of the NifA-binding site to the IHF-binding site could lead to competition between NifA and IHF, affecting nif $A$ expression in $H$. seropedicae.

The partial $\mathrm{N}$-terminal amino acid sequence of the ORF $3^{\prime}$ from nif $A$ in $H$. seropedicae showed extensive homology with those of the NifB proteins from Azotobacter vinelandii and B. japonicum. The homology of the $\mathrm{N}$-terminal of the putative $\mathrm{Nif} \mathrm{B}$ of $\mathrm{H}$. seropedicae is closer to that of B. japonicum $(68 \%)$ or Azotobacter vinelandii $(66 \%)$ than to that of K. pneumoniae $(53 \%$ ) (not shown). The cysteine cluster, postulated to bind metal during the processing of FeMo-co (Buikema et al., 1987), is conserved, as well as most of the amino acid residues surrounding it. A $-24 /-12$ promoter sequence and two NifA-binding sites were identified in the nif $B$ promoter region (Fig. $5 c$ ), suggesting that transcription of nif promoters in $H$. seropedicae could be regulated by the NifA protein and dependent on the $\sigma^{54}$ factor (RpoN). The presence of a doublet of NifA-binding sites in the promoter region of nif $B$-like gene has been described before in $R$. meliloti (Buikema et al., 1987) and Azotobacter vinelandii (Joerger \& Bishop, 1988) and may be involved in transcriptional control.

This is the first nif $A$-like gene of a member of the Spirillaceae to be sequenced, as well as the first evidence supporting the existence of the $n$ if $A$ in the Spirillaceae 
since the work of Pedrosa \& Yates (1984). Our results indicate that expression of the nif $A$ gene in $H$. seropedicae may be $\mathrm{RpoN}$ - and $\mathrm{NtrC}$-dependent, and thus analogous to that of $K$. pneumoniae, but that it may also be regulated by the NifA protein. Whether this regulation, if it occurs, is negative or positive remains to be determined. We have found no evidence for a nif $L$ type gene in $H$. seropedicae and it is possible that oxygen (and nitrogen) regulation of nif expression in this organism is mediated by the interdomain region of the NifA protein.

We are especially thankful to Christina Kennedy, Ray Dixon, Martin Drummond, Martin Buck and Paul Woodley for helpful suggestions and to Richard Pau and Mike Merrick for help with the computer analysis. We also thank Mike Merrick and Barry Smith for reading the manuscript and Mrs Rosemary Foote for typing. We are grateful to all members of the genetics section of the Nitrogen Fixation Laboratory for advice and encouragement and thank CNPq, CONCITEC and CAPES for financial support. The DNA sequencing reported here was undertaken and completed by the senior author (E.M.S.) while on a visiting fellowship at the IPSR Nitrogen Fixation Laboratory.

\section{References}

Baldani, J. I., Baldani, V. L. D., Seldin, L. \& Döbereiner, J. (1986). Characterization of Herbaspirillum seropedicae gen. nov., sp. nov., a root-associated nitrogen-fixing bacterium. International Journal of Systematic Bacteriology 36, 86-93.

Bankier, A. T., Weston, K. M. \& Barrel, B. G. (1987). Random cloning and sequencing by the M13/dideoxynucleotide chain termination method. Methods in Enzymology 155, 51-93.

Bennett, L. T., Cannon, F. \& Dean, D. R. (1988). Nucleotide sequence and mutagenesis of the nif $A$ gene from Azotobacter vinelandii. Molecular Microbiology 2, 315-321.

Bozouklian, H. \& Elmerich, C. (1986). Nucleotide sequence of the Azospirillum brasilense $\mathrm{Sp} 7$ glutamine synthetase structural gene. Biochimie 68, 1181-1187.

Bozouklian, H., Fogher, C. \& Elmerich, C. (1986). Cloning and characterization of the $g \ln A$ gene of Azospirillum brasilense $\mathrm{Sp} 7$. Annales de l'Institut Pasteur 137B, 3-18.

de Bruijn, F. J., Pawlowski, K., Ratet, P., Hilgert, U., Wong, C. H., SCHNeider, M., MeYer, H. Z. A. \& SChell, J. (1988). Molecular genetics of nitrogen fixation by Azorhizobium caulinodans ORS571, the diazotrophic stem nodulating symbiont of Sesbania rostrata. In Nitrogen Fixation: One Hundred Years After, pp. 351-355. Edited by H. Bothe, F. J. de Bruijn \& W. E. Newton. Stuttgart: Gustav Fischer.

Buchanan-Wollaston, V., Cannon, M. C., Beynon, J. L. \& CANNON, F. C. (1981). Role of the nif $A$ gene product in the regulation of nif expression in Klebsiella pneumoniae. Nature, London 294, 776-778.

Buikema, W. J., Szeto, W. W., Lemley, P. V., Orme-Johnson, W. H. \& AUSUBEL, F. M. (1985). Nitrogen fixation specific regulatory genes of Klebsiella pneumoniae and Rhizobium meliloti share homology with the general nitrogen regulatory gene ntrC of $K$. pneumoniae. Nucleic Acids Research 13, 4539-4555.

Buikema, W. J., Kingensmith, J. A., Gibbons, S. L. \& Ausubel, F. M. (1987). Conservation of structure and location of Rhizobium meliloti and Klebsiella pneumoniae nif B genes. Journal of Bacteriology 169, $1120-1126$.

Cannon, W. V., Kreutzer, R., Kent, H. M., Morett, E. \& Buck, M. (1990). Activation of the Klebsiella nifU promoter: identification of multiple and overlapping upstream NifA binding sites. Nucleic Acids Research 18, 1693-1701.
DevereuX, J., Haerberli, P. \& Smithies, O. (1984). A comprehensive set of sequence analysis programs for the VAX. Nucleic Acids Research 12, 387-395.

Dixon, R. (1988). Genetic regulation of nitrogen fixation. Symposia of the Society for General Microbiology 42, 417-438.

Drummond, M., Clements, J., Merrick, M. \& Dixon, R. A. (1983). Positive control and autogenous regulation of the nif $L A$ promoter in Klebsiella pneumoniae. Nature, London 301, 302-307.

DRUMmond, M., WhitTY, P. \& WootTon, J. (1986). Sequence and domains relationship of $n t r C$ and nif $A$ from Klebsiella pneumoniae: homologies to other regulatory proteins. EMBO Journal 5, 441-447.

FalK, E. C., Johnson, J. L., Baldani, V. L. D., Döbereiner, J. \& KRIEG, N. R. (1986). Deoxyribonucleic and ribonucleic acid homology studies of the genera Azospirillum and Conglomeromonas. International Journal of Systematic Bacteriology 36, 80-85.

Feinberg, A. P. \& Vogelstein, B. (1984). A technique for radiolabeling DNA restriction endonuclease fragments to high specific activity. Analytical Biochemistry 137, 266-267.

FISCHER, H. M. \& HENNECKE, H. (1987). Direct response of Bradyrhizobium japonicum nif $A$-mediated nif gene regulation to cellular oxygen status. Molecular and General Genetics 209, 621-626.

FisCHER, H. M., BRUDERER, T. \& HeNNECKE, H. (1988). Essential and non essential domains in the Bradyrhizobium japonicum NifA protein: identification of indispensable cysteine residues potentially involved in redox reactivity and/or metal binding. Nucleic Acids Research 16, 2207-2224.

GOODRICH, J. A., SchWartZ, M. L. \& MCCluRe, W. (1990). Searching for and predicting the activity of sites for DNA binding proteins: compilation and analysis of the binding sites for Escherichia coli integration host factor (IHF). Nucleic Acids Research 18, 4993-5000.

Grönger, P., Manian S. S., Reiländer, H., O'Connell, M., Priefer, U. B. \& Pühler, A. (1987). Organization and partial sequence of a DNA region of the Rhizobium leguminosarum symbiotic plasmid pRL6JI containing the genes $f i x A B C$, nif $A$, nif $B$ and a novel open reading frame. Nucleic Acids Research 15, 31-49.

Gussin, G. N., Ronson, C. W. \& Ausubel, F. M. (1986). Regulation of nitrogen fixation genes. Annual Review of Genetics 20, 567-591.

Higgins, D. G. \& Sharp, P. M. (1988). Clustal: a package for performing multiple sequence alignment on a microcomputer. Gene 73, 237-244.

Hoover, T. R., Santero, E., Porter, S. \& Kustu, S. (1990). The integration host factor stimulates interaction of RNA polymerase with NifA, the transcriptional activator for nitrogen fixation operons. Cell 63, 11-22.

JoERGER, R. D. \& Bishop, P. E. (1988). Nucleotide sequence and genetic analysis of the nif $B$-nif $Q$ region from $A$ zotobacter vinelandii. Journal of Bacteriology 170, 1475-1487.

Maniatis, T., Fritsch, E. F. \& Sambrook, J. (1982). Molecular Cloning: A Laboratory Manual. Cold Spring Harbor, NY: Cold Spring Harbor Laboratory.

MASEPOHL, B., KLIPP, W. \& PÜHLER, A. (1988). Genetic characterization and sequence analysis of the duplicated nif $A /$ nif $B$ gene region of Rhodobacter capsulatus. Molecular and General Genetics 212, 27-37.

Mead, D. A., Szczena-Skorupa, E. \& Kemper, B. (1986). Single stranded DNA 'blue' $\mathrm{T} 7$ promoter plasmids: a versatile tandem promoter system for cloning and protein engineering. Protein Engineering 1, 67-74.

MerricK, M. J. (1983). Nitrogen control of the nif regulon in Klebsiella pneumoniae: involvement of the ntrA gene and analogies between ntrC and nif A. EMBO Journal 2, 39-44.

Nees, D. W., Stein, P. A. \& Ludwig, R. A. (1988). The Azorhizobium caulinodans nif $A$ gene: identification of upstream activating sequences including a new element, the 'anaerobox'. Nucleic Acids Research 16, 9839-9853.

Noti, J. D., Folkerts, O., Turken, A. N. \& Szalay, A. A. (1986). Organization and characterization of genes essential for symbiotic nitrogen fixation from Bradyrhizobium japonicum I110. Journal of Bacteriology 167, 774-783.

Pedrosa, F. O. \& Yates, M. G. (1984). Regulation of nitrogen fixation (nif) genes of Azospirillum brasilense by nif $A$ and $n t r(g \ln )$ type gene products. FEMS Microbiology Letters 23, 95-101. 
Ronson, C. W., Nixon, B. T., Albright, C. M. \& Ausubel, F. M (1987). Rhizobium meliloti ntrA (rpoN) gene is required for diverse metabolic functions. Journal of Bacteriology 169, 2424-2431.

Santero, E., Toukdarian, A., Humphrey, R. \& KenNedy, C. (1988). Identification and characterization of two nitrogen fixation regulatory regions, nif $A$ and $n f r X$, in Azotobacter vinelandii and Azotobacter chroococcum. Molecular Microbiology 2, 303-314.

SANTero, E., Hoover, T., Keener, J. \& Kustu, S. (1989). In vitro activity of the nitrogen fixation regulatory protein NifA. Proceedings of the National Academy of Sciences of the United States of America 86, 7346-7350.

Souza, E. M., Funayama, S., Rigo, L. \& Pedrosa, F. O. (1991). Cloning and characterization of the nif $A$ gene from Herbaspirillum seropedicae. Canadian Journal of Microbiology 37, 425-429.

StaDEN, R. (1982). Automation of the computer handling of gel reading data produced by the shotgun method of DNA sequencing. Nucleic Acids Research 10, 4731-4751.
STADEN, R. (1984). Graphic methods to determine the function of nucleic acid sequences. Nucleic Acids Research 12, 521-538.

THÖNY, B., ANTHAMATTEN, D. \& HENNECKE, H. (1989). Dual control of the Bradyrhizobium japonicum symbiotic nitrogen fixation regulatory operon fixRnif A : analysis of cis- and trans-acting elements. Journal of Bacteriology 171, 4162-4169.

TOUKDARIAN, A. \& KenNEDY, C. (1986). Regulation of nitrogen metabolism in Azotobacter vinelandii: isolation of $n t r$ and $g \ln A$ genes and construction of ntr mutants. EMBO Journal 5, 399-407.

Walker, J. E., Saraste, M., Runswick, M. J. \& Gay, N. J. (1982). Distantly related sequences in the $\alpha$ and $\beta$ subunits of ATP synthase, myosin, kinases and other ATP-requiring enzymes and a common nucleotide binding fold. EMBO Journal 1, 945-951.

YANG, C. C. \& NASH, H. A. (1989). The interaction of E. coli IHF protein with its specific binding sites. Cell 57, 869-880. 